\title{
Kebutuhan Bahan Ajar Matakuliah Biologi Sel di Perguruan Tinggi Kota Malang
}

\author{
Iin Murtini ${ }^{1}$, Siti Zubaidah ${ }^{1}$, Dwi Listyorini ${ }^{1}$ \\ ${ }^{1}$ Pendidikan Biologi-Universitas Negeri Malang
}

\begin{tabular}{l}
\hline \hline INFO ARTIKEL \\
\hline Riwayat Artikel: \\
Diterima: $17-05-2019$ \\
Disetujui: $23-08-2019$ \\
\hline
\end{tabular}

\section{Kata kunci:}

teaching materials;

cell biology:

college;

bahan ajar;

biologi sel;

perguruan tinggi

\begin{abstract}
ABSTRAK
Abstract: The purpose of this research was to find out the teaching materials that needed to be developed in Cell Biology courses at Malang City Universities. The study was conducted on students who have taken Cell Biology courses in four college at the Malang city. The type of research conducted is quantitative descriptive research. The results showed that students were interested in Cell Biology courses and in the Cell Biology course there were several topics which were considered difficult including cell division, cell division control, and cancer, while for the results of the study related to the availability of teaching materials used, data were obtained that in three universities, namely UNISMA, UMM, and IKIP Budi Utomo, the percentage was more than 50\% while for UIN the percentage was $48 \%$. Students consider teaching that has not been able to construct understanding of concepts in studying Cell Biology courses so it is necessary to develop research-based module teaching materials.
\end{abstract}

\begin{abstract}
Abstrak: Tujuan penelitian ini adalah untuk mengetahui bahan ajar yang perlu dikembangkan pada matakuliah Biologi Sel di Perguruan Tinggi Kota Malang. Penelitian dilakukan terhadap mahasiswa yang telah menempuh matakuliah Biologi Sel di empat Perguruan Tinggi kota Malang. Jenis penelitian yang dilakukan adalah penelitian deksriptif kuantitatif. Hasil penelitian menunjukkan bahwa mahasiswa tertarik pada matakuliah Biologi Sel dan pada matakuliah Biologi Sel terdapat beberapa topik yang dianggap sulit antara lain pembelahan sel, pengendalian pembelahan sel, dan kanker. Hasil penelitian terkait ketersediaan bahan ajar yang digunakan diperoleh data bahwa pada tiga perguruan tinggi yaitu UNISMA, UMM, dan IKIP Budi Utomo diperoleh persentase lebih dari $50 \%$ sedangkan untuk UIN didapatkan persentase sebesar $48 \%$. Mahasiswa menganggap ajar yang digunakan belum dapat mengonstruk pemahaman konsep dalam mempelajari matakuliah Biologi Sel sehingga perlu adanya pengembangan bahan ajar modul berbasis penelitian.
\end{abstract}

\author{
Alamat Korespondensi: \\ Iin Murtini \\ Pendidikan Biologi \\ Universitas Negeri Malang \\ Jalan Semarang 5 Malang \\ E-mail: iin.moertiny@gmail.com
}

\begin{abstract}
Abad 21 merupakan masa pengetahuan (knowledge age) dimana setiap manusia memenuhi kebutuhannya dengan menggunakan ilmu pengetahuan yang diperoleh melalui bidang pendidikan. Pendidikan abad 21 perlu mempertimbangkan berbagai hal, baik kompetensi lulusan, isi/konten pendidikan, maupun proses pembelajarannya sehingga dapat merangsang, mendorong, dan membiasakan peserta didik secara aktif mencari informasi dari berbagai sumber (BSNP, 2010). Tuntutan pendidikan abad 21 ini menjadi sebuah tantangan bagi pendidik untuk menciptakan pembelajaran yang berkualitas dengan berbekal kompetensi pedadogik, kepribadian, sosial dan profesional. Kegiatan pembelajaran merupakan interaksi antara pendidik dan peserta didik yang berlangsung dalam situasi pengajaran untuk mencapai tujuan pembelajaran (Surya, 2014). Peserta didik juga berinteraksi dengan lingkungan untuk mempelajari berbagai bidang ilmu, salah satunya adalah biologi. Kajian materi ilmu biologi dalam konteks perkuliahan memiliki cakupan yang cukup luas, salah satunya yaitu matakuliah Biologi Sel.

Biologi Sel merupakan matakuliah wajib ditempuh mahasiswa S1 jurusan biologi maupun pendidikan biologi. Pada matakuliah Biologi Sel terdapat beberapa topik yang dibahas, salah satunya adalah pembelahan sel. Pembelahan sel merupakan topik yang sulit dipahami karena melibatkan beberapa gen yang berperan dalam pengendalian pembelahan sel, sehingga dalam mempelajarinya dibutuhkan bahan ajar yang mendukung untuk mencapai tujuan pembelajaran. Bahan ajar merupakan merupakan hal yang penting dalam proses pembelajaran, untuk membantu peserta didik memahami materi yang dipelajari. Pendidik yang profesional diharapkan memiliki kemampuan mengembangkan bahan ajar sesuai ketentuan yang ada dengan memperhatikan karakteristik dan lingkungan sosial peserta didiknya (Depdiknas, 2008a).
\end{abstract}


Bahan ajar merupakan segala bahan yang disusun secara sistematis dan digunakan dalam proses pembelajaran dengan menggambarkan kompetensi yang akan dikuasai peserta didik, misalnya buku pelajaran, modul, handout, LKS, model atau maket, bahan ajar audio, dan bahan ajar interaktif lainnya (Prastowo, 2012). Pada dasarnya bahan ajar atau materi pembelajaran (instructional materials) terdiri atas pengetahuan, keterampilan dan sikap yang harus dipelajari peserta didik dalam rangka mencapai standar kompetensi yang telah ditentukan (Kristanto, 2011). Bahan ajar yang dirancang dengan baik dan terstruktur sangat berpengaruh pada tingkat keberhasilan proses pembelajaran (Kurniawan, Pujaningsih, Alrizal, \& Latifah, 2018). Tujuan penelitian ini adalah untuk mengetahui jenis bahan ajar yang perlu dikembangkan pada matakuliah Biologi Sel di Perguruan Tinggi Kota Malang. Hasil penelitian ini diharapkan dapat memberikan informasi mengenai jenis bahan ajar yang perlu dikembangkan supaya dapat membantu dalam pencapaian tujuan pembelajaran.

\section{METODE}

Penelitian ini menggunakan pendekatan deskriptif kualitatif. Subjek pada penelitian ini yaitu mahasiswa yang telah menempuh matakuliah Biologi Sel di empat perguruan tinggi berbeda, yaitu Universitas Islam Negeri Maulana Malik Ibrahim (UIN) Malang, Universitas Islam Malang (UNISMA), Universitas Muhammadiyah Malang (UMM), dan IKIP Budi Utomo yang dilakukan pada semester ganjil tahun ajaran 2017/2018. Sampel penelitian ini diambil secara acak dengan menggunakan teknik random sampling. Prosedur penelitian yang dilakukan adalah dengan memberikan angket mengenai kebutuhan mahasiswa terhadap matakuliah Biologi Sel pada dosen dan mahasiswa. Teknik analisis data yang digunakan yaitu analisis deskriptif terhadap hasil angket dosen dan mahasiswa.

\section{HASIL}

Penelitian ini dilakukan dengan menelaah kurikulum matakuliah Biologi Sel dan mendapatkan respon dosen maupun mahasiswa mengenai pembelajaran di kelas serta harapan ke depannya terkait proses pembelajaran pada matakuliah Biologi Sel. Hasil penelitian menunjukkan bahwa mahasiswa sangat tertarik terhadap matakuliah Biologi Sel. Hal ini dapat dilihat dari persentase yang diperoleh dari masing-masing perguruan tinggi. Pada UIN Malang diperoleh hasil sebesar 75\%, UNISMA sebesar 100\%, UMM sebesar 90\%, IKIP Budi Utomo sebesar 100\%. Hasil penelitian juga menunjukkan bahwa mahasiswa mengalami kesulitan dalam memahami materi Biologi Sel dengan persentase sebesar $68 \%$ pada perguruan tinggi UIN Malang, $75 \%$ pada UNISMA, $85 \%$ pada UMM, dan 60\% pada IKIP Budi Utomo. Hasil penelitian tentang ketersediaan bahan ajar biologi sel menunjukan hasil yang bervariasi, hal ini dapat dilihat dari persentase yang diperoleh dari masing-masing perguruan tinggi. Pada UIN diperoleh sebesar 48\%, UNISMA sebesar 70\%, UMM sebesar 60\%, dan IKIP Budi Utomo sebesar 57\%. Ketersediaan bahan ajar dan penggunaan buku-buku penunjang pada UIN Malang belum cukup memadai dalam proses perkuliahan pada matakuliah Biologi Sel sehingga menyebabkan mahasiswa mengalami kesulitan dalam mengembangkan ilmu pengetahuannya. Hal ini berbeda dengan UNISMA, UMM dan IKIP Budi Utomo yang ketersediaannya diatas 50\%. Hasil penelitian terkait ketertarikan pada matakuliah Biologi Sel, topik yang dianggap sulit, dan ketersediaan bahan ajar yang ditunjukkan pada gambar 1 .

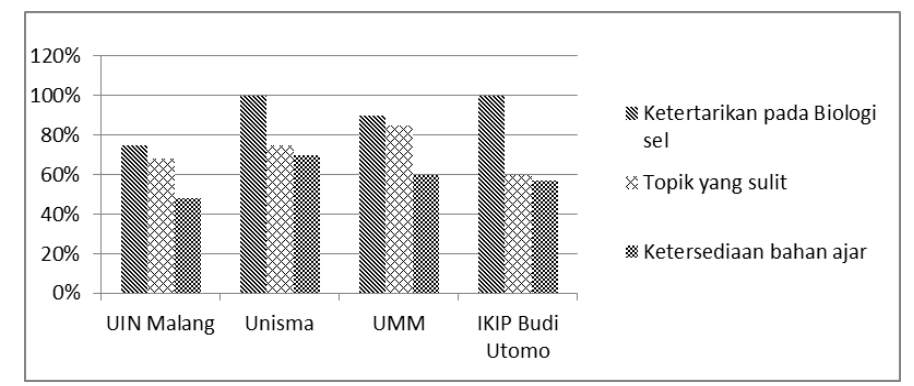

\section{Gambar 1. Ketertarikan pada Matakuliah Biologi Sel dan Kesulitan Memahami Materi}

Hasil analisis kebutuhan pada mahasiswa (tabel 1) juga diperoleh data mengenai topik pada matakuliah Biologi Sel yang dianggap sulit oleh mahasiswa dan jenis media yang digunakan dalam pembelajaran. Hasil penelitian menunjukkan bahwa topik yang dianggap paling sulit pada matakuliah Biologi Sel adalah pembelahan sel, pengendalian pembelahan sel, dan kanker, sedangkan jenis media ajar yang digunakan dalam pembelajaran adalah powerpoint, petunjuk praktikum dan handout. Hal ini dapat dilihat dari persentase yang diperoleh pada masing-masing Perguruan Tinggi. Angket juga diberikan kepada dosen untuk mengetahui pendapat dosen terkait pembelajaran pada matakuliah Biologi Sel. Hasil analisis angket yang diberikan kepada dosen di perguruan tinggi yang berbeda ditunjukkan pada tabel 2. 
Tabel 1. Hasil Analisis Angket Mahasiswa

\begin{tabular}{llcccc}
\hline \multirow{2}{*}{ Aspek } & \multicolumn{1}{c}{ Indikator } & \multicolumn{4}{c}{ Perguruan Tinggi } \\
\cline { 3 - 5 } & & UIN & UNISMA & UMM & IKIP Budi Utomo \\
\hline Topik yang dianggap sulit & Struktur sel & $11 \%$ & $13 \%$ & $1 \%$ & $10.3 \%$ \\
& Pembelahan sel & $13 \%$ & $20 \%$ & $34 \%$ & $28.8 \%$ \\
& Pengendalian pembelahan sel & $26 \%$ & $42.5 \%$ & $24 \%$ & $40 \%$ \\
& Kanker & $28 \%$ & $19.5 \%$ & $34 \%$ & $11.9 \%$ \\
& Apoptosis & $20 \%$ & $5 \%$ & $7 \%$ & $9 \%$ \\
\hline Media yang digunakan & Powerpoint & $48 \%$ & $18 \%$ & $74 \%$ & $38.5 \%$ \\
& Petunjuk praktikum & $17 \%$ & $35.5 \%$ & $6 \%$ & $28.4 \%$ \\
& Modul & $11 \%$ & $10 \%$ & $1 \%$ & $0 \%$ \\
& Handout & $20 \%$ & $18.8 \%$ & $17 \%$ & $12.6 \%$ \\
& Media lainnya & $4 \%$ & $17.7 \%$ & $2 \%$ & $20.5 \%$ \\
\hline
\end{tabular}

Tabel 2. Hasil Analisis Angket Dosen

\begin{tabular}{|c|c|c|}
\hline Aspek & Perguruan Tinggi & Hasil Analisis \\
\hline Ketertarikan pada matakuliah & UIN & Semua mahasiswa tertarik pada matakuliah Biologi Sel \\
\hline \multirow[t]{3}{*}{ Biologi Sel } & UNISMA & \\
\hline & UMM & \\
\hline & IKIP Budi Utomo & \\
\hline \multirow{4}{*}{$\begin{array}{l}\text { Topik yang dianggap sulit oleh } \\
\text { mahasiswa }\end{array}$} & UIN & Pengendalian Pembelahan Sel \\
\hline & UNISMA & Tidak ada yang sulit \\
\hline & UMM & Apoptosis \\
\hline & IKIP Budi Utomo & Pembelahan Sel \\
\hline \multirow{4}{*}{$\begin{array}{l}\text { Kendala dalam kegiatan } \\
\text { pembelajaran }\end{array}$} & UIN & Kemampuan mahasiswa beragam \\
\hline & UNISMA & Bahan-bahan praktikum yang mahal \\
\hline & UMM & Susah mencari gambar yang sesuai \\
\hline & IKIP Budi Utomo & Keterbatasan bahan ajar \\
\hline \multirow[t]{4}{*}{ Strategi yang digunakan } & UIN & Media interaktif, misalnya video simulasi. \\
\hline & UNISMA & Jurnal penelitian tentang molekuler \\
\hline & UMM & Menggunakan contoh misalnya gambar, dan membuat dua kelompok \\
\hline & IKIP Budi Utomo & $\begin{array}{l}\text { Menggunakan model pembelajaran yang sesuai, media yang mendukung } \\
\text { dan praktikum sederhana }\end{array}$ \\
\hline \multirow[t]{4}{*}{ Media yang digunakan } & UIN & Powerpoint, handout, dan buku penunjang lainnya. \\
\hline & UNISMA & Power point dan jurnal hasil penelitian. \\
\hline & UMM & Powerpoint, handout, dan buku berbahasa asing. \\
\hline & IKIP Budi Utomo & Powerpoint dan media animasi, modul. \\
\hline Saran & & Perlu dikembangkan modul yang dilengkapi hasil penelitian \\
\hline
\end{tabular}

\section{PEMBAHASAN}

Berdasarkan hasil angket analisis kebutuhan didapatkan data bahwa mahasiswa tertarik mempelajari Biologi Sel. Hasil angket yang diberikan pada dosen juga menyatakan bahwa mahasiswa sangat tertarik mempelajari matakuliah Biologi Sel karena mahasiswa sangat antusias dan aktif ketika mengikuti proses pembelajaran Biologi Sel. Pada matakuliah Biologi Sel juga terdapat beberapa topik yang perlu dikaji lebih dalam, yaitu pembelahan sel, pengendalian pembelahan sel, kanker, dan apoptosis yang disebabkan oleh belum adanya media belajar yang mendukung, materinya yang kompleks, serta tidak ada penjelasan secara mendetail terkait dengan materi tersebut. Hal ini sejalan dengan hasil analisis angket dari dosen yang menyatakan bahwa topik yang dianggap sulit oleh mahasiswa yaitu pembelahan sel, pengendalian pembelahan sel, dan apoptosis. Penelitian terdahulu juga melaporkan bahwa pembelahan sel merupakan topik yang dianggap paling sulit bagi mahasiswa (Chattopadhyay, 2012; Lewis \& Wood-Robinson, 2000). Pada topik pembelahan sel sering terjadi miskonsepsi, baik pada jenjang SMA maupun perguruan tinggi (Chattopadhyay, 2012).

Hasil analisis angket dosen diperoleh data bahwa selain adanya topik yang dianggap sulit, terdapat juga kendala selama proses perkuliahan Biologi Sel yaitu materi yang kompleks, daya serap mahasiswa yang tidak seragam, terbatasnya bahan-bahan praktikum, contoh gambar yang sesuai topik sulit didapatkan, dan keterbatasan bahan ajar. Dosen pada masing-masing perguruan tinggi memiliki strategi yang berbeda untuk diterapkan dalam proses pembelajaran, hal ini disebabkan kendala yang dialami setiap perguruan tinggi juga berbeda. Pada dasarnya penggunaan berbagai strategi dalam proses pembelajaran untuk membantu mahasiswa memahami materi secara utuh. Strategi yang digunakan dosen UIN dalam proses pembelajaran yaitu dengan 
menggunakan media interaktif, misalnya video simulasi, sedangkan dosen UNISMA menggunakan jurnal penelitian tentang molekuler untuk membantu proses pembelajaran. Dosen IKIP menggunakan model pembelajaran yang sesuai, media yang mendukung dan praktikum sederhana, dan Dosen UMM menggunakan strategi dengan pemberian contoh pada setiap topik sehingga mengharuskan mahasiswa mencari gambar untuk mempermudah dalam memahami materi. Berbagai media pembelajaran digunakan untuk mempermudah dalam memahami konsep materi. Salah satu media pembelajaran yang sangat dibutuhkan dalam pembelajaran supaya dapat menunjang perkuliahan adalah bahan ajar.

Hasil analisis angket kebutuhan pada mahasiswa menunjukkan bahwa bahan ajar yang digunakan dalam proses pembelajaran berupa powerpoint, handout, modul, dan sumber lain yang berasal dari internet. Hal ini diperkuat dengan data hasil analisis kebutuhan pada dosen terkait media yang sering digunakan yaitu powerpoint, handout, media animasi, jurnal, modul, dan buku berbahasa asing. Namun, bahan ajar yang digunakan selama ini masih belum dapat membantu mahasiswa dalam memahami materi sehingga perlu dikembangkan bahan ajar yang dapat membantu mahasiswa mempelajarinya dengan cara mandiri. Hasil angket oleh dosen menyatakan bahwa perlu dikembangkan sebuah modul dengan isi mudah dipahami yang dilengkapi dengan hasil-hasil penelitian terkini yang menunjang konsep-konsep dasar dalam Biologi Sel sehingga mahasiswa dapat lebih banyak belajar secara mandiri daripada terus menerus diberikan materi oleh dosen. Penelitian terdahulu melaporkan bahwa penggunaan modul dalam pembelajaran akan membantu pembelajaran menjadi lebih efektif, efisien, dan relevan (Wena, 2009).

Modul adalah bahan ajar yang dirancang secara sistematis dan dikemas dalam bentuk satuan pembelajaran terkecil yang dapat dipelajari secara mandiri dalam satuan waktu tertentu (Purwanto, 2007). Pembelajaran dengan menggunakan modul bersifat pembelajaran mandiri karena memberikan kesempatan kepada mahasiswa untuk mengelola waktu belajarnya dan memahami materi perkuliahan secara mandiri. Modul memiliki karakteristik stand alone, self-instruction, self-contained, adaptive dan user friendly (Depdiknas, 2008b). Modul dapat membantu menciptakan pembelajaran yang berkualitas dan mengkondisikan pembelajaran lebih terencana, terarah, dan hasil belajarnya pun jelas (Ikhsan, Sutarno, \& Prayitno, 2016). Materi yang disusun secara sistematis juga dapat mempermudah pengguna untuk belajar secara mandiri (Sanjaya, Kiswardianta, \& Pujiati, 2017). Pembelajaran akan bermakna jika menggunakan bahan ajar modul yang disusun berdasarkan hasil penelitian karena modul yang dikembangkan dengan mengintegrasikan hasil-hasil penelitian efektif digunakan dalam pembelajaran (Peniati, 2012). Penelitian terdahulu menyatakan bahwa penyusunan materi ajar berdasarkan hasil penelitian akan mendapatkan informasi yang akurat, terbaru dan berkelanjutan (Handayani, 2015).

\section{SIMPULAN}

Berdasarkan hasil penelitian dapat disimpulkan bahwa mahasiswa memerlukan bahan ajar yang dapat membangun pengetahuannya sendiri dan dapat dipelajari secara mandiri yaitu berupa modul berbasis penelitian. Pada dasarnya penelitian ini merupakan penelitian tahap awal yang dilakukan dalam proses pengembangan bahan ajar berupa modul berbasis penelitian sehingga kedepannya masih dibutuhkan penelitian lanjutan guna mengukur tingkat validitas dan praktikalitas modul yang dikembangkan.

\section{DAFTAR RUJUKAN}

BSNP. (2010). Paradigma Pendidikan Nasional di Abad-21. Jakarta: Badan Standar Nasional Pendidikan.

Chattopadhyay, A. (2012). Understanding of Mitosis and Meiosis in Higher Secondary Students of Northeast India and the Implications for Genetics Education. Education, 2(3), 41-47. https://doi.org/10.5923/j.edu.20120203.04

Depdiknas. (2008a). Panduan Pengembangan Bahan Ajar (Diretorat Jendral Manajemen Pendidikan Dasar dan Menengah, Ed.). Jakarta.

Depdiknas. (2008b). Penulisan Modul. Jakarta: Direktorat Tenaga Kependidikan, Dirjen Peningkatan Mutu Pendidik dan Tenaga Kependidikan, Departemen Pendidikan Nasional.

Handayani, S. (2015). Pengembangan Modul Pembelajaran berbasis Pengujian di Laboratorium sebagai Upaya Peningkatan Kompetensi. Prosiding Konvensi Nasional APTEKINDO VII dan Temu Karya XVIII FPTK/FT-JPTK Se-Indonesia

Ikhsan, M., Sutarno, S., \& Prayitno, B. A. (2016). Pengembangan Modul Berbasis Inkuiri Terbimbing pada Materi Sistem Gerak Manusia untuk Meningkatkan Hasil Belajar Siswa Kelas XI MIA SMA Negeri 1 Wera Kabupaten Bima Nusa Tenggara Barat. Jurnal Inkuiri, 5(1), 133-142.

Kristanto, D. D. (2011). Pokok Bahasan Gerak pada Siswa SMA Kelas X Semester 1 SMA Negeri 1 Purwareja Klampok. Unnes.

Kurniawan, W., Pujaningsih, F. B., Alrizal, A., \& Latifah, N. A. (2018). Analisis Kebutuhan Mahasiswa terhadap Bahan Ajar sebagai Acuan untuk Pengembangan Modul Fisika Gelombang Bola dan Tabung. EduFisika: Jurnal Pendidikan Fisika, $3(1), 17-25$.

Lewis, J., \& Wood-Robinson, C. (2000). Genes, Chromosomes, Cell Division and Inheritance-Do Students See Any Relationship? International Journal of Science Education, 22(2), 177-195. https://doi.org/10.1080/095006900289949 
Peniati, E. (2012). Pengembangan Modul Matakuliah Strategi Belajar Mengajar IPA Berbasis Hasil Penelitian Pembelajaran. Jurnal Pendidikan IPA Indonesia, 1(1), 8-15. https://doi.org/10.15294/jpii.v1i1.2006

Prastowo, A. (2012). Panduan Kreatif Membuat Bahan Ajar Inovatif. Jogjakarta: Diva Press.

Purwanto, P. (2007). Pengembangan Modul. Jakarta: Pusat Teknologi Informasi dan Komunikasi Pendidikan Departemen Pendidikan Nasional.

Sanjaya, F. M., Kiswardianta, R. B., \& Pujiati, P. (2017). Penyusunan Modul Zat Pengawet Makanan Kelas VIII SMP Berbasis Penelitian Zat Antibakteri. In Prosiding Seminar Nasional Simbiosis, 2(September), 310-314.

Surya, M. (2014). Psikologi Guru Konsep dan Aplikasi. Bandung: Alfabeta.

Wena, M. (2009). Strategi Pembelajaran Inovatif Kontemporer. Jakarta: Bumi Aksara. 